\title{
Peningkatan Kecepatan Efektif Membaca (KEM) Siswa Kelas XI SMAN 1 Blitar Pada Mapel Bahasa Indonesia Menggunakan Metode Klos
}

\author{
Titik Mahanani ${ }^{(1)}$ \\ ${ }^{1}$ SMAN 1 Blitar \\ Email: ${ }^{1}$ tutikmahanani65@gmail.com, \\ DOI: https://doi.org/10.28926/riset_konseptual.v2i2.43
}

\begin{abstract}
ABSTRAK
Tujuan penelitian tindakan kelas ini yaitu untuk meningkatkan Kecepatan Efektif Membaca (KEM) dengan menggunakan metode klos siswa kelas XI SMA Negeri 1 Blitar. Penelitian tindakan kelas ini mengambil setting di SMA Negeri 1 Blitar kelas XI, dengan jumlah siswa 34 siswa. Pelaksanaan kegiatan dilaksanakan melalui tiga siklus. Hasil penelitian pada siklus I tingkat keterbacaannya masih rendah, karena kecepatan efektif membaca rata-rata $87 \mathrm{kpm}$ dengan tingkat Independen $18 \%$ tingkat instruktional $38 \%$ dan pada frustasi $44 \%$. Pada siklus II hasil penelitian mengalami perubahan positif yaitu kecepatan efektif membaca rata-rata 150 $\mathrm{kpm}$ dengan tingkat Independen $78 \%$ tingkat Instruksional 18\%, dan tingkat frustasi $4 \%$. Hasil penelitian pada siklus III mengalami pemantapan yaitu rata-rata Kecepatan Efektif Membaca (KEM) $210 \mathrm{kpm}$ dengan tingkat independen 100\%. Hasil analisis data menunjukkan bahwa aktivitas pembelajaran membaca cepat dengan menggunakan metode klos dapat meningkatkan Kecepatan Efektif Membaca (KEM) siswa.
\end{abstract}

Kata kunci: kecepatan efektif membaca, klos, bahasa indonesia,

\section{PENDAHULUAN}

Selama ini model pembelajarannya selalu mengacu pada apa yang ada dalam buku paket. Teknik pengajaran membaca yang ada umumnya membaca pemahaman. Salah satu tehnik membaca yang dapat diterapkan yaitu teknik uji rumpang. Guru Bahasa Indonesia pada umumnya hanya mengutamakan penyelesaian target materi dalam kurikulum yang orientasinya mengacu pada usaha meningkatkan kemampuan siswa dalam mengerjakan soal-soal, walaupun hal ini tidak selalu benar sebab soalsoal sering kurang mengacu pada keterampilan berbahasa baik keterampilan menyimak, berbicara, membaca, maupun menulis.

Berdasarkan uraian singkat di atas, peneliti mengambil tindakan, yaitu "Meningkatkan Kecepatan Efektif Membaca (KEM) dengan Menggunakan Metode Klos pada Pelajaran Bahasa Indonesia Siswa Kelas XI SMA Negeri Blitar pada Semester Ganjil Tahun Akademik 2012/2013. Peneliti memilih metode klos untuk meningkatkan Kecepatan Efektif Membaca (KEM) karena metode klos dapat dipakai untuk mengukur tingkat keterbacaan sebuah wacana untuk melatih keterampilan dan kemampuan dan membaca.

Tujuan Penelitian dalam penelitian ini yaitu untuk mengetahui pengaruh penggunaan metode Klos dalam meningkatkan Kecepatan Efektif Membaca (KEM) siswa kelas XI SMA Negeri Blitar. Lingkup yang menjadi batasan materi dalam penelitian ini adalah Kecepatan Efektif Membaca (KEM) pada mata pelajaran Bahasa Indonesia dengan kompetensi dasar membaca cepat. Penelitian dilaksanakan pada siswa kelas XI SMA Negeri 1 Blitar Kota Blitar pada Semester Genap Tahun Akademik 2012/2013.

Hasil dari penelitian ini diharapkan dapat memberi manfaat bagi siswa, guru (peneliti), rekan sesama guru, dan sekolah. Bagi siswa hasil penelitian ini diharapkan dapat meningkatkan keterampilan berbahasa dan terjadi kemajuan belajar pada mata pelajaran lain. Bagi peneliti (guru) dapat meningkatkan profesionalisme dan bisa 
digunakan untuk pengembangan profesi dalam perolehan angka kredit untuk naik ke golongan IV b. Bagi guru lain memberikan motivasi dan referensi model-model pembelajaran yang inovatif. Bagi sekolah dengan adanya guru-guru (para peneliti) melakukan penelitian tindakan kelas berarti proses pembelajaran di kelas sangat berkualitas sehingga terjadi perubahan positif mengarah pada sekolah unggul.

\section{METODE \\ Pendekatan dan Jenis Penelitian}

Pendekatan yang digunakan dalam penelitian ini adalah pendekatan kualitatif. Jenis penelitian yang digunakan adalah penelitian tindakan, yaitu peneliti berusaha untuk menerapkan suatu tindakan sebagai upaya perbaikan untuk mengatasi masalah yang ditemukan.

\section{Model Penelitian}

Penelitian ini adalah penelitian tindakan kelas, model Stephen Kemmis dan Mc Taggart (dalam Suranto 200:49), model ini menggunakan sistem spiral refleksi diri yang dimulai dari rencana, tindakan, pengamatan, refleksi, dan perencanaan kembali yang merupakan dasar untuk suatu rancangan pemecahan masalah.

\section{Prosedur Penelitian}

Prosedur penelitian diawali dengan pra tindakan yaitu mengadakan identifikasi metode klos dan Kecepatan Efektif Membaca (KEM) kemudian baru dilaksanakan tindakan yang terdiri dari 3 siklus, Setiap siklus tindakannya ada empat tahapan yaitu (I) persiapan perencanaan tindakan. (2) pelaksanaan tindakan, 3) observasi dan evaluasi, dan (4) analisis dan refleksi.

\section{Data dan Sumber Data}

Data yang dikumpulkan dalam penelitian ini berupa catatan-catatan, silabus pembelajaran, rencana pelaksanaan pembelajaran (RPP). hasil Kecepatan Efektif Membaca (KEM) siswa, dan hasil observasi terhadap kegiatan pembelajaran. Sumber data dalam penelitian ini adalah siswa kelas XI SMA Negeri 1 Blitar pada Semester Ganjil tahun Akademik 2012/2013, dan guru. serta pengamat selama berlangsungnya penilaian tindakan kelas.

\section{Teknik Analisis Data}

Analisis kualitatif terhadap data kualitatif yang diperoleh dari hasil pengamatan siswa dan guru selama berlangsungnya pembelajaran di kelas. Sedangkan analisis kuantitatif dilakukan terhadap hasil tes Kecepatan Efektif Membaca (KEM) siswa dengan menggunakan Metode Klos. Rumus yang dipakai untuk mengetahui Kecepatan Efektif Membaca adalah sebagai berikut:

$\mathrm{K} / \mathrm{Wm} \times \mathrm{B} / \mathrm{SI}=\ldots . \mathrm{Kpm}$

Keterangan

$\mathrm{K}=$ Jumlah kata yang dibaca

$\mathrm{Wm}=$ Waktu tempuh baca dalam satuan menit

$\mathrm{B}=$ Skor bobot perolehan tes yang dijawab dengan benar

SI = Skor ideal atau skor maksimal

$\mathrm{Kpm}=$ Kata per menit

Siswa dikatakan berhasil membaca (tuntas) kalau kecepatan membaca minimal $250 \mathrm{kpm}$ dan kemampuan memahami bacaan minimal 70\%, itu berarti siswa dikatakan berhasil membaca (tuntas) atau sesuai dengan KKM (Kriteria Ketuntasan Minimal) yaitu jika kecepatan efektif membaca (KEM) minimal 175 kpm (Harjasujana, 2000:110). 


\section{Lokasi Penelitian}

Lokasi penelitian tindakan kelas ini yaitu SMA Negeri 1 Blitar Tahun Akademik 2012/2013. Penelitia ini dilakukan di kelas yang dipilih secara acak kelas XI dengan jumlah 34 siswa. Lokasi sekolah di jalan A. Yani No. 112 Kecamatan Sananwetan Kota Blitar, Penelitian tindakan kelas ini menggunakan kompetensi dasar membaca cepat dalam mata pelajaran bahasa Indonesia.

\section{HASIL \\ Pra Tindakan}

Siswa mendengarkan penjelasan tentang metode klos dan Kecepatan Efektif Membaca (KEM), kemudian siswa berdiskusi tentang penggunaan metode klos untuk meningkatkan Kecepatan Efektif Membaca (KEM), bahkan hal ini dikondisikan menjadi diskusi kelas. Ternyata siswa sangat tertarik dengan metode klos. Hal ini terlihat banyaknya siswa yang bertanya dan juga memberikan tanggapan, pertanyaan maupun tanggapan berkisar tentang metode klos dan KEM.

\section{Siklus I \\ Persiapan Tindakan Siklus I}

Mempersiapkan alat observasi baik untuk siswa maupun guru. Alat observasi berupa instrumen metode klos, instrumen alat penilaian individu KEM siswa, instrumen observasi KEM, instrumen observasi aktivitas guru, dan angket siswa. Peneliti dibantu observer dari guru dan juga pengamat dari siswa.

\section{Pelaksanaan Tindakan Siklus I}

Pelaksanaan tindakan pada siklus I memerlukan 2 (dua) kali tatap muka, setiap tatap muka memerlukan 2x45 menit dengan langkah-langkah pembelajaran sebagai berikut: (a) siswa membentuk kelompok, (b) siswa mencatat tujuan pembelajaran yang akan dicapai, (c) kelompok $A$ yaitu kelompok nomor absen ganjil membaca wacana yang sudah disediakan dan siswa kelompok B yaitu kelompok nomor absen genap mencatat dan menghitung responden, (d) kelompok B (sebagai pengamat) secara individu mengukur tingkat keterbacaan responden (pasangannya), (e) kelompok yang semula sebagai responden berganti sebagai kelompok pengamat, begitu juga sebaliknya, (f) siswa berdiskusi tentang kendala meningkatkan KEM dengan menggunakan Metode Klos sebagai acuan refleksi.

\section{Observasi dan Evaluasi Siklus I}

Hasil uji kemampuan isian rumpang yaitu, (a) Tingkat Independen 6 siswa 17,5 \%, (b) Tingkat instruksional 13 siswa 37,5\%, (c) Tingkat Frustasi 15 siswa 45\%. Kecepatan Efektif Membaca (KEM) siswa yang tuntas atau sesuai dengan Kriteria Ketuntasan Minimal yaitu 175 kata permenit ke atas adalah 0 siswa siswa yang tidak tuntas atau kurang dari 175 kata permenit ke atas adalah 34 siswa siswa yang KEMnya tertinggi $170 \mathrm{kpm}$, KEM terendah $30 \mathrm{kpm}$, dan KEM rata-rata $87 \mathrm{kpm}$.

\section{Analisis dan Refleksi Siklus I}

Dari masalah yang dihadapi siswa selama membaca dengan menggunakan metode klos, maka dapat direfleksikan (a) Siswa perlu meningkatkan pengetahuan bahasa Indonesia dengan jalan sering membaca Kamus Bahasa Indonesia, dan tentang teori kebahasaan. (b) Siswa perlu meningkatkan kemapuan kognitif dengan jalan meningkatkan daya nalar dan kepekaaan untuk mengerti dan memahami isi pesan yang terkandung dalam suatu bacaan yang seefisien mungkin. (c) Siswa harus sering membaca untuk meningkatkan pengalaman membaca. (d) Guru/peneliti perlu memproduksi wacana yang dominan dan menghindari wacana yang terpinggirkan yaitu wacana yang berfungsi membentuk dan mengkondisikan wacana aktual. 


\section{Siklus II}

\section{Persiapan Tindakan Siklus II}

Pada persiapan tindakan kelas di siklus II ini seperti juga pada persiapan tindakan kelas di siklus I, namun di siklus ini persiapannya sebagai tindak lanjut, Rencana pelaksanaan pembelajaran RPP) dibuat oleh peneliti/guru dibantu oleh dua orang pengamat dari guru mata pelajaran sejenis. Bacaan dipersiapkan sebagai wacana yang aktual (dominan) berjudul "Tembak di Tempat Perusuh, Pejarah dan Koruptor Bahasa Indonesia".

\section{Pelaksanaan Tindakan Siklus II}

Pelaksanaan tindakan pada siklus ini gurupeneliti menerapkan pembelajaran dengan langkah-langkah sebagai berikut (a) Kegiatan awal siswa membentuk kelompok seperti pada siklus 1 dan siswa mencatat tujuan pembelajaran. (b) Siswa nomor absen ganjil membaca teks non sastra berjudul "Tembak di Tempat Perusuh, Pejarah dan Koruptor Bahasa Indonesia" yang panjang wacana kurang lebih 400 kata dan waktu membaca yang disediakan 2 menit. (c) Setelah 2 menit bacaan diambil oleh guru, kemudian siswa tersebut diberi teks lagi dengan teks yang sama tetapi dirumpangi sebanyak 15 rumpangan, dan siswa diberi kesempatan mengerjakan selama 10 menit. (d) Siswa yang nomor absen genap sebagai pengamat yang bertugas mengukur tingkat keterbacaan responden (pasangannya). (e) Tahap berikutnya kelompok yang semula sebagai responden berganti sebagai kelompok pengamat yang tugasnya mencatat waktu dan menghitung KEM responden, begitu juga kelompok yang semula sebagai pengamat berganti menjadi kelompok responden

\section{Observasi dan Evaluasi Siklus II}

Hasil uji kemampuan isian rumpang pada tingkat indipenden sebanyak 30 orang atau $77 \%$, pada tingkat instrusional sebanyak 6 orang atau $17,5 \%$ dan pada tingkat frustasi gagal sebanyak 2 orang atau $5 \%$. Hal ini banyak mengalami peningkatan apabila dibandingkan dengan siklus I. Kecepatan Efektif Membaca (KEM) siswa pada penelitian ini terekam sebagai berikut: (a) KEM siswa yang tuntas sesuai dengan kriteria ketuntasan minimal (KEM $=175 \mathrm{kpm}$ ke atas) adalah 18 siswa atau $45 \%$, yang tidak tuntas 22 siswa atau $55 \%$. Hal ini pun mengalami kenaikan apabila dibandingkan dengan siklus I. Pada siklus II ini KEM tertinggi $217 \mathrm{kpm}$, terendah 70 $\mathrm{kpm}$, dan rata-rata $150 \mathrm{kpm}$.

\section{Analisis dan Refleksi Siklus II}

Permasalahan siswa yang sudah ada jalan keluarnya sebagai pelaksanaan refleksi perlu diteruskan, mengingat hasilnya sangat membanggakan tentamasiswa diharapkan terus mengembangkan pengalaman membaca dengan cara sering membaca untuk melatih Kecepatan Efektif Membaca (KEM).

\section{Siklus III}

\section{Persiapan Tindakan Siklus III}

Pada persiapan tindakan, guru peneliti mempersiapkan rencana pelaksanaan pembelajaran (RPP), dan bahan ajar peneliti langsung menggunakan bacaan 250 kata dengan waktu membaca direncanakan hanya 1 menit. Lembar observasi untuk mengetahui KEM maupun angket untuk siswa juga dipersiapkan agar penelitian tindakan kelas ini bisa maksimal.

\section{Pelaksanaan Tindakan Siklus III}

Pelaksanaan tindakan pada siklus III ini merupakan siklus akhir. Guru/peneliti menerapkan pembelajaran dengan langkah-langkah sehagai berikut: (a) siswa membentuk kelompok seperti pada siklus sebelumnya, (b) siswa mencatat tujuan pembelajaran yang akan dicapai, (c) siswa dengan nomor absen ganjil membaca teks 
non sastra berjudul "Tertib Lalu Lintas" dalam 1 menit, (d) setelah selesai, siswa tersebut diberi teks lagi dengan teks yang sama tetapi ada rumpangan sebanyak 15 rumpangan, (e) siswa mengerjakan dengan waktu yang disediakan 10 menit, (f) siswa yang nomor absen genap sebagai pengamat yang bertugas mengukur tingkat keterbatassan responden, $(\mathrm{g})$ selanjutnya kelompok yang semula sebagai responden berganti sebagai kelompok pengamat dan kelompok yang semula sebagai pengamat berganti menjadi kelompok responden.

\section{Observasi dan Evaluasi Siklus III}

Hasil uji kemampuan isian rumpang menunjukkan tingkat independen $=40$ siswa atau $100 \%$, tingkat instruksional=0 siswa atau $0 \%$, dan tingkat frustasi/gagal=0 siswa atau 0\%. Hasil obsrvasi menunjukkan KEM siswa yang tuntas sebanyak 34 siswa.

\section{Analisis dan Refleksi Siklus III}

Di akhir siklus ini guru/peneliti memberikan angket kepada siswa tentang pelaksaan pembelajaran, ternyata siswa menyambut posistif pelaksanaan pembelajaran yang dilakukan oleh guru/peneliti. Siswa menyatakan bahwa pembelajaran dengan metode klos dapat meningkatkan KEM. Dengan demikian pelaksaan pembelajaran sampai dengan siklus II mencapai keberhasilan.

\section{PEMBAHASAN}

Pada proses pembelajaran guru harus pandai-pandai memilih model pembelajaran. Pembelajaran bahasa Indonesia harus bisa menerapkan keterampilan berbahasa. Ada 4 aspek keterampilan berbahasa yaitu menyimak, berbicara, dan menulis baik itu tentang kebahasaan maupun kesastraan.

Membaca merupakan bagian penting dari 4 aspek keterampilan berbahasa. Membaca banyak ragamnya tenaasuk membaca cepat. Tidak sedikit siswa menggunakan metode klos untuk meningkatkan KEM siswa. Pada penelitian tindakan kelas (PTK) ini pada siklus ke III ternyata semua siswa KEMnya $175 \mathrm{kpm}$ ke atas. Menurut Kamidjan (996:68) metode klos dapat dipakai untuk mengukur tingkat keterbacaan sebuah wacana yaitu (a) dapat dipakai untuk menguji tingkat kesukaran dan tingkat kemudahan suatu wacana. (b) dapat mengklasifikasikan pembaca menjadi 3 kelompok, yaitu: independen (tingkat bebas), instruksional (tingkat pengajaran), dan frustasi (gagal), (c) serta untuk mengetahui kelayakan wacana sesuai dengan kemampuan siswa (Karmidjan, 1996:68).

Sejalan dengan itu beliau juga mengatakan teknik klos juga dapat dipakai untuk melatih keterampilan dan kemampuan membaca. Yang diperhatikan dalam melatih keterampilan dan kemampuan baca ialah: (a) dalam menggunakan isyarat sintaksis, (b) dalam menggunakan isyarat semantik, (c) dalam menggunakan isyarat skematis, (d) dalam menggunakan jumlah kosakata, (e) dalam melatih daya nalar pembaca, serta (f dalam melatih pemahaman bacaan (Kamidjan, 996:69).

Kegiatan awal pembelajaran pada pra tindakan terlihat semua siswa tertarik penjelasan guru tentang model/teknik klos dan penjelasan KEM (Kecepatan Efektif Membaca) seseorang, bahkan pada saat berdiskusi tentang metode tersebut siswa sangat antusias bertanya dan memberikan komentar maupun pendapat. Hal ini sangat relevan apabila metode klos digunakan untuk meningkatkan KEM, karena siswa ada kepedulian. Itu berarti pembelajaran yang bermakna dan menyenangkan telah terbentuk, dan sangat baik untuk memulai tindakan baik siklus I maupun siklus-siklus berikutnya.

Pelaksanaan refleksi dengan jalan diksusi kelompok maupun diskusi kelas telah teruji bahwa kendala kendala KEM harus segera diatasi agar KEM siswa meningkat. Menurut Harjasujana (2000:90), kendala-kendala KEM meliputi lemahnya pengetahuan bahasa, kurangnya kemampuan kognitif, dan pengalaman membaca yang memprihatinkan. Masalah pengetahuan bahasa jalan keluarnya siswa diharapkan 
sering membaca kamus bahasa Indonesia, dan untuk kemampuan kognitif, siswa diharapkaan meningkatkan daya nalar dan kepekaan untuk mempermudah memahami isi pesan yang terkandung dan yang terakhir yaitu pada kendala pengalaman membaca diharapkan siswa sering membaca karena seseorang yang sering membaca KEMnya jauh berbeda dengan orang yang jarang membaca. Itu berarti bahwa untuk mencapai tujuan perlu melihat sebab, kalau sudah tahu sebab. baru melangkah mencari jalan keluar.

\section{KESIMPULAN}

Metode klos dapat dipakai untuk mengukur tingkat keterbacaan sebuah wacana yaitu dapat dipakai untuk menguji tingkat kesukaran dan tingkat kemudahan suatu wacana, serta dapat mengklasifikasi pembaca menjadi 3 kelompok yaitu dependen (tingkat bebas), instruksional (tingkat pengajaran), dan frustasi (gagal). Hasil analisis data menunjukkan bahwa aktivitas pembelajaran membaca cepat dengan menggunakan metode klos dapat meningkatkan Kecepatan Efektif Membaca (KEM) siswa.

\section{SARAN}

Agar mampu terampil membaca sebaiknya dilatih dan diajarkan mulai tingkat dasar, karena kemampuan membaca mempunyai pengaruh terhadap mata pelajaran lain. Serta untuk melatih membaca tepat, benar dan cepat menjadi tanggung jawab semua guru dan bukan tanggung jawab guru bahasa Indonesia saja.

\section{DAFTAR RUJUKAN}

Depdikbud. 1999. Penelitian Tindakan. Jakarta Direktorat Jendral Pendidikan Dasar dan Menengah, Direktorat Menengah Umum.

Eriyanto. 2003. Analisis Wacana. Yogyakarta: LKIS.

Harjosujono, Akhmad Slamet, 1996. Membaca 2. Jakarta Depdikbud Direktorat. Jendral Pendidikan Dasar dan Menengah. Direktorat Menengah Umum. Bagian Proyek Penataran Baru SLTP Setara D.III.

Kasmidjan. 1996. Teori Membaca. Surabaya: Jurusan Pendidikan Bahasa dan Sastra Indonesia Fakultas Pendidikan Bahasa dan Seni.

Poerwodarminto, WJS. 1994. Bahasa Indonesia untuk Karang Mengarang. Yogya: UP. Indonesia.

Soedarso. 2000. Speed Reading Sistem Membaca Cepat dan Efektif. Jakarta PT Gramedia Pustaka Utama.

Subyakto, Sri Utari. 1988. Metodologi Pengajaran Bahasa. Jakarta: Depdikbud Direktorat Jenderal Pendidikan Tinggi, Proyek Pengembangan Lembaga Pendidikan Tenaga Kependidikan.

Suranto, Basowi, Sukidin. 2002. Manajemen Penelitian Tindakan Kelas. Insan Cendikia.

Tim Pelatih Proyek PGSM. 1999. Penelitian Tindakan Kelas (PTK). Jakarta: Depdikbud Direktorat Pendidikan Tinggi, Pengembangan Guru Sekolah Menengah. 
JURNAL PENDIDIKAN: Riset \& Konseptual

http://journal.unublitar.ac.id/pendidikan/index.php/Riset_Konseptual

Vol. 2 No. 2, April 2018;
E-ISSN: 2598-2877

P-ISSN: 2598-5175 